\section{ISOKINETIC RESPONSE, VISCOSUPPLEMENTATION AND STRENGTH TRAINING IN GONARTHROSIS}

\author{
RESPOSTA ISOCINÉTICA, VISCOSSUPLEMENTAÇÃO E TREINAMENTO DE FORÇA EM GONARTROSE \\ RESPUESTA ISOCINÉTICA, VISCOSUPLEMENTACIÓN Y ENTRENAMIENTO DE FUERZA EN GONARTROSIS
}

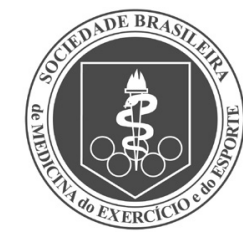

Original Article

ARTIGO ORIGINAL Artículo Original
Paulo Cesar Hamdan 1 (DD
(Physician)
Humberto Lameira Miranda ${ }^{2}$ (D)
(Physical Education Professional)
Thiago Gomes de Paula 3 (ID
(Physical Education Professional)
Eduardo Becker Nicoliche ${ }^{4}$ (D)
(Physical Education Professional)
Victor Rodrigues Amaral Cossich ${ }^{4}$
(Physical Education Professional)
Jose Inácio Salles Neto ${ }^{4}$ (D
(Physical Education Professional)

1. Universidade Federal do Rio de Janeiro, Hospital Universitário Clementino Fraga Filho, Rheumatology Service, Orthopedics, Rheumatology and Physiatrics Center, Strength Training Center, Rio de Janeiro, RJ, Brazil.

2. Universidade Federal do Rio de Janeiro, School of Physical Education, Strength Training Laboratory, Rio de Janeiro, RJ, Brazil.

3. Centro Ortopédico Reumatológico e Fisiátrico, Strength Training Center, Rio de Janeiro, RJ, Brazil.

4. Instituto de Traumatologia e Ortopedia do Rio de Janeiro, Neuromuscular Research Laboratory, Rio de Janeiro, RJ, Brazil.

\section{Correspondence:}

Paulo Cesar Hamdan.

Hospital Universitário Clementino Fraga Filho (HUCFF/UFRJ), Rua Professor Rodolpho Rocco, 255, Cidade Universitária, Illha do Fundão, Serviço de Reumatologia $9^{\circ}$ andar. Rio de Janeiro, RJ, Brazil. 21941-590. paulohamdan@yahoo.com.br; hamdanacademico@yahoo.com

\begin{abstract}
Introduction:Viscosupplementation and strength training are proposed interventions in the treatment of knee osteoarthritis. Objective: To describe the isokinetic response in women with knee osteoarthritis who underwent both interventions. Methods: A double-blind, randomized clinical trial involving thirty women diagnosed with grade II and III bilateral knee osteoarthritis using the radiological criteria of Kellgren \& Lawrence. The subjects were randomized into three groups of ten patients each: one group was submitted to viscosupplementation and strength training (VST), another was submitted to strength training (ST) only, and a third to viscosupplementation (VS) only. All evaluations followed the study phases defined as pre-procedure (PRE); after 48 hours of VS (POS-VS); after 12 weeks of training (POST); and after eight weeks of detraining (POS D). Intra-articular knee infiltrations were performed with a single dose of Hylan GF-20 and isokinetic dynamometry to determine the maximum torque in knee extension and flexion. Pain was measured by the visual analogue scale (VAS). Results: The interventions promoted improvements in the isokinetic response in all three groups and in both muscle groups, with advantage for the extensor group. A significant difference was noticed in the isokinetic response of the trained groups when compared only to the viscosupplemented group ( $p<0.005$ ), and the VST group showed better isokinetic response compared to the ST group. Conclusion: Combined treatment with viscosupplementation and strength training, and treatment with strength training only, presented better results in terms of isokinetic response and pain reduction than viscosupplementation alone. Level of evidence l; Therapeutic studies-Investigating the results of treatment.
\end{abstract}

Keywords: Strength training; Viscosupplementation; Osteoarthritis, knee

\section{RESUMO}

Introdução: Viscossuplementação e treinamento de força são intervenções propostas no tratamento da osteoartrite de joelho. Objetivo: Descrever a resposta isocinética em mulheres com osteoartrite dejoelho submetidas a ambas intervenções. Métodos: Ensaio clínico duplo-cego e randomizado envolvendo 30 mulheres com diagnóstico de osteoartrite bilateral de joelho de graus II elll utilizando os critérios radiológicos de Kellgren \& Lawrence. Elas foram randomizadas em três grupos de dez pacientes cada: um grupo foi submetido à viscossuplementação e ao treinamento de força (VTF), o outro submetido ao treinamento de força (TF) e o terceiro grupo foi submetido apenas à viscossuplementação (VS). Todas as avaliações seguiram as fases do estudo definidas como pré-procedimento (PRE); após 48 horas da VS (POS-VS); após 12 semanas de treinamento (POS T) e após oito semanas de destreinamento (POSD). Foram realizadas infiltrações intra-articulares de joelho com uma dose única de Hilano GF-20 e dinamometria isocinética para determinar o torque máximo em extensão eem flexão do joelho. A dor foi medida através da escala visual analógica (EVA). Resultados: As intervenções promoveram melhorias na resposta isocinética em todos os três grupos e em ambos grupos musculares, com vantagem para o grupo extensor. Observou-se uma diferença significativa na resposta isocinética dos grupos treinados quando comparados ao grupo somente viscossuplementado $(p<0,005)$, além disso o grupo VTF apresentou melhor resposta isocinética quando comparado ao grupo TF. Conclusão: O tratamento combinado de viscossuplementação e treinamento de força e o tratamento com o treinamento de força apenas apresentaram melhores resultados na resposta isocinética e na redução da dor do que o tratamento apenas com viscossuplementação. Nível de evidência l; Estudos terapêuticos-Investigação dos resultados do tratamento.

Descritores: Treinamento de força; Viscossuplementação; Osteoartrite do joelho.

\section{RESUMEN}

Introducción: Viscosuplementación y entrenamiento de fuerza son intervenciones propuestas en el tratamiento de osteoartritis de rodilla. Objetivo: Describir la respuesta isocinética en mujeres con osteoartritis de rodilla sometidas a ambas intervenciones. Métodos: Ensayo clínico doble ciego y aleatorizado que involucró a 30 mujeres con diagnóstico de osteoartritis bilateral de rodilla de grados II y III utilizando los criterios radiológicos de Kellgren y Lawrence. Ellas fueron aleatorizadas en tres grupos con diez pacientes cada uno: un grupo fue sometido a viscosuplementación y al entrenamiento de fuerza (VEF), el otro sometido al entrenamiento de fuerza (EF) yel tercer grupo sometido sólo a la viscosuplementación (VS). Todas las evaluaciones siguieron las fases del estudio definidas como pre-procedimiento (PRE); después de 48 horas de la VS (POS-VS); después de 12 semanas de entrenamiento (POSE) y después de ocho semanas de desentrenamiento (POSD). Fueron realizadas infiltraciones intraarticulares de rodilla con una dosis única de Hilano GF-20y dinamometría isocinética para determinar el torque máximo en extensión yen flexión de rodilla. El dolor fue medido a través de la escala visual analógica (EVA) Resultados: Las intervenciones promovieron mejoras en la respuesta isocinética en los tres gruposy 
en ambos grupos musculares, con ventaja para el grupo extensor. Se observó una significativa diferencia en la respuesta isocinética de los grupos entrenados cuando comparados solamente al grupo viscosuplementado ( $p<0,005)$, además el grupo VEF presentó mejor respuesta isocinética cuando comparado al grupo EF. Conclusión: El tratamiento combinado de viscosuplementación y entrenamiento de fuerza y el tratamiento con entrenamiento de fuerza sólo presentaron mejores resultados en la respuesta isocinética yen la reducción del dolor que el tratamiento con sólo viscosuplementación. Nivel de evidencia l; Estudios terapéuticos-Investigación de los resultados del tratamiento.

\section{Descriptores: Entrenamiento de fuerza; Viscosuplementación; Osteoartritis de la rodilla.}

\section{INTRODUCTION}

Osteoarthritis $(\mathrm{OA})$ is currently considered a clinical syndrome derived from the unbalance between the formation and destruction of cartilage, which involves multiple systemic, genetic, inflammatory, and mechanical factors with the active participation of the synovia, the cartilage, and of the subchondral bone resulting in the so-called joint insufficiency.1-3 Occours loss of muscular strength, functionality, stability, and joint amplitude changing the balance., Among the phenotypes, knee osteoarthritis (KOA) is the most manifested by the accumulation of loads, which the joint is required to support significantly increasing its demand ${ }^{4}$ by decreasing the torque in the concentric and eccentric quadriceps and hamstrings forces..$^{5-7}$ The indication of exercise in KOA patients is no longer discussed and should be recommended as a non-pharmacological option for disease management and control. ${ }^{8-10}$ However, there is still a discussion about the existence of a really effective intervention for the treatment of KOA. ${ }^{11}$ As a pharmacological proposal, viscosuppplementation (VIS) is an effective pain relief procedure with sustainable effect, good tolerability, safety and efficacy. Therefore, it is indicated in the failure of other therapies or as a non-surgical option. 12-16 Its use is indicated for the treatment of grade II and III KOA (11) and approved by different clinical trials. ${ }^{15,16}$

In Brazil, there are very few studies considering the effects of ST in the treatment of $\mathrm{KOA}^{17,18}$ becoming even scarcer when seeking to measure them with isokinetic response. ${ }^{6}$ It seems there are no studies that compare them with VIS effects. In this study, the isokinetic response is evaluated in both flexors and extensors of female knees with bilateral KOA level II and III19,20 underwent only VIS, only ST, and both procedures.

\section{METHODS}

Thirty sedentary women, without performing any kind of exercises for a minimum period of six months, were evaluated at the Laboratório de Pesquisas Neuromusculares do Instituto Nacional de Traumato Ortopedia (PNEURO / INTO).

They were followed at the rheumatology service of the Hospital Universitário Clementino Fraga Filho da Universidade Federal do Rio de Janeiro (HUCFF/UFRJ) with clinical and radiological diagnosis of grade II and III KOA 19,20 with pain self-report by the Visual Scale. Analog (VAS) equal to or greater than 6 and Body Mass Index (BMI) below 39. Patients with psychiatric disorders that make it difficult to understand the study, under 40 years of age, who had comorbidities or cardiovascular risk to exercise, changes in joint morphology or biomechanics, already submitted or eligible for any surgical procedure. Patients with any avian protein-related hypersensitivity were also excluded. Regarding losses, the lack of more than one of the evaluations was considered as total and, partially, the lack of one of the evaluations.

The study was approved by the HUCFF/UFRJ Research Ethics Committee, under opinion No. 41376814.3.0000.5257 and the Brazilian Registry of Clinical Trials - RBR-4zx26w. All participants signed an informed consent form.
They were randomized into three groups: group $1=$ underwent VIS and ST (VST); group 2 = underwent ST only (ST) and group $3=$ underwent VIS (VS) only. The study collaborators, isokinetic evaluator and physical educator were masked in relation to randomizations.

ST sessions were held at the Centro de Treinamento de Força do Centro Ortopédico Reumatológico e Fisiátrico (CTF-CORF). The training load was prescribed according to the results obtained in the 10-RM test performed until voluntary concentric muscle failure, with a three-minute interval between sets. ${ }^{21,22}$ Participants were instructed individually on the technique of performing each exercise. None of them completed the 10-RM test. Thus, the minimum load of the extension and flexor chair equipments was used as the initial load for all participants was $5 \mathrm{~kg}$ (PRE), performing the exercises in a slow and controlled manner, with three seconds for the concentric phase and three seconds for the eccentric phase of the movement. The training was performed during twelve weeks with sessions supervised and monitored by the same Physical Educator, according to the following periodization: two sets of ten repetitions, three times a week, with an initial load of $5 \mathrm{~kg}$, ending a volume of $300 \mathrm{~kg}$ weekly. ${ }^{21,22}$ The loads were reevaluated every four weeks, individually modifying the training volume according to the achieved load, 21,22 until completing twelve weeks of training (POS T). After this period, the training sessions were interrupted for eight weeks (POST D). Evaluations followed the pre-procedure (PRE) phases of the study: 48 hours after VIS (POS-VS), after 12 weeks of training (POS T) and finally after eight weeks of detraining (POS D).

The studies of isokenetic dynamometry of the three groups happened at PNEURO/INTO in order to determine the maximum extension and flexion torques of the knee, in phases PRE, POS-VS, POS T, and POS $D$. To evaluate muscle strength an isokinetic dynamometer - CSMI, model HUMAC NORM - was used. Subjects sat with the lateral femoral condyle aligned with the axis of rotation of the machine and the ankle attached to the stem component, knee attachment was strapped on using velcro. To determine maximum voluntary strength, isokinetic concentric-concentric knee flexion and extension tests within the velocity protocol of $60 \%$ s in five repetitions were used. The highest instant torque found was considered the peak torque and used for the analysis. ${ }^{23}$ Before testing procedure, all patients performed warm-up exercise in a cycloergometer (5 min., 60 watts).

Intra-articular knee injections using HGF-20 or VIS were used in all patients. The VST and VS groups were viscosupplemented after first isokinetic evaluation, while ST group, after the conclusion of the study. The viscosupplementation injections were assisted by ultrasound. The VIS was a single dose of $6 \mathrm{ml} / 48 \mathrm{mg}$ with $6.000 .000 \mathrm{kDa}$ of HGF-20 in each knee. ${ }^{15}$ After infiltrations, patients were instructed to rest for 48 hours. ${ }^{12-16}$

A single examiner applied a specific instrument, Visual Analogue Scale (VAS), to assess perceived pain in the PRÉ, PÓS-VS, PÓST e PÓS D phases. 


\section{Statistical analysis}

Statistical Package for Social Sciences (SPSS) version 20.0 software was used and one-way ANOVA and two-way ANOVA analyzes were performed for repeated measures to identify intragroup differences between the moments. A significance level of 5\% ( $p<0.05)$ was considered.

\section{RESULTS}

Of 96 patients eligible for the clinical trial, 46 patients did not meet the initial inclusion criteria. Twenty additional patients refused to participate. Of the 30 participants included in the research, 20 had grade II osteoarthritis and 10 had grade III osteoarthritis. Two partial losses occurred in the detraining phase (POS D).

Demographic data show a higher mean age and BMI in the VS group, with equivalent KOA degrees of severity (50\%). The second lowest mean age and BMI were found in the ST group with $80 \%$ of the lowest cases of KOA $(n=8)$. The VST group had the lowest mean age among the three groups, with a BMI average higher than the ST group and lower than the VS group and $70 \%$ of the cases of lower KOA severity $(n=7)$. (Table 1)

In order to evaluate the existence of a mutual relationship between age and radiological severity of the sample, Pearson's correlation coefficient was used. In the sample, there was a positive correlation between the level of radiological severity and age, neither perfect $(<1)$ nor diffuse $(>0)$. (Table 2 )

Both ST and VIS proved to be efficient in the treatment of KOA, regardless of its degree. There was a reduction in pain and an increase in isokinetic response when comparing the values of the PRE period to those of the POST T period without reversal of the effect and those of the POST D period in the three groups. (Table 3)

There was no difference between interventions for most outcomes studied, however with exceptions: (1) trained groups had better isokinetic results compared to VS group, (2) VST group, although without significant difference, had better isokinetic response than ST group (Table 3) and (3) there was interaction between momentum and intervention confirming the visco-antalgic effect in the POST-VS and sustained, in the POST T and POST D periods. These patients, even without training, showed evolution of isokinetic response. (Table 3)

\section{DISCUSSION}

Analyzing results, in relation to the average age and percentage of the degree of severity of the disease, it was observed: in the VS group, higher average and percentage equivalence; in the ST group, the second lowest average and lowest percentage and, in the VST group, the lowest average and percentage (Table 1). Thus, it was expected to find, in the initial isokinetic response, the highest peak torque in the VST group, then in the ST group and the lowest in the VS group. It is noteworthy that these groups were obtained after randomization and before evaluations, which could have been performed after the initial isokinetic evaluation and formed equivalent groups, considering the triad: peak torque, age and disease severity. However, a selection bias would be configured; Therefore, it was decided to use objective instruments, thus ensuring neutrality in the moments of evaluation and training. As predicted, peak torque at PRE moment was reduced when compared to POS-VS, POS T, and POS D moments.
Table 2. Correlation Age x Disease severity.

\begin{tabular}{c|c|c|c|c|c}
\hline \multirow{2}{*}{ Groups } & \multirow{2}{*}{ Age } & \multicolumn{2}{|c|}{ Radiological } & \multirow{2}{*}{ Correlation } & \multirow{2}{*}{ Agreement } \\
\cline { 3 - 4 } & & Level II & Level III & & \\
\hline VSST & $61.90 \pm 7.23$ & 7 & 3 & $r=0.35$ & Light \\
\hline ST & $64.00 \pm 8.82$ & 8 & 2 & $r=-0.12$ & Poor \\
\hline VS & $67.80 \pm 9.1$ & 5 & 5 & $r=0.55$ & Moderate \\
\hline
\end{tabular}

Table 3. Outcome.

\begin{tabular}{c|c|c|c|c|c}
\hline & Pre & Pos VS & Pos T & Pos D & P-value \\
\hline \multicolumn{5}{c}{ Extension isokinetic response (average \pm DP) Peak torque (Nm. kg-1). } \\
\hline VSST+ VS & $0.92 \pm 0.33$ & $0.96 \pm 0.33$ & NA & NA & $0.367^{*}$ \\
\hline VSST & $1.08 \pm 0.38$ & NA & $1.17 \pm 0.44$ & $1.14 \pm 0.40$ & $\mathrm{p}<0.05^{* *}$ \\
\hline SF & $1.05 \pm 0.24$ & NA & $1.16 \pm 0.23$ & $1.14 \pm 0.15$ & $\mathrm{p}<0.05^{* *}$ \\
\hline VS & $0.76 \pm 0.16$ & NA & $0.77 \pm 0.12$ & $0.73 \pm 0.14$ & NA
\end{tabular}

\begin{tabular}{c|c|c|c|c|c}
\hline \multicolumn{5}{c}{ Flexion isokinetic response (average \pm DP) Peak torque (Nm. kg-1). } \\
\hline VSST/NS & $0.60 \pm 0.23$ & $0.66 \pm 0.23$ & NA & NA & $0.125^{*}$ \\
\hline VSST & $0.71 \pm 0.28$ & NA & $0.81 \pm 0.29$ & $0.79 \pm 0.26$ & $p<0.05^{* *}$ \\
\hline SF & $0.69 \pm 0.13$ & NA & $0.73 \pm 0.19$ & $0.78 \pm 0.15$ & $p<0.05^{* *}$ \\
\hline VS & $0.50 \pm 0.11$ & NA & $0.57 \pm 0.14$ & $0.53 \pm 0.16$ & NA \\
\hline
\end{tabular}

EVA (average \pm DP)

\begin{tabular}{c|c|c|c|c|c}
\hline VSST + VS & $7.45 \pm 1.19$ & $3.80 \pm 0.83$ & NA & NA & $<0.001$ \\
\hline VSST & $7.1 \pm 0.88$ & NA & $1.8 \pm 0.79$ & $1.9 \pm 0.88$ & $<0.001$ \\
\hline ST & $6.5 \pm 0.71$ & NA & $2.0 \pm 1.25$ & $2.4 \pm 1.43$ & $<0.001$ \\
\hline VS & $7.8 \pm 1.40$ & NA & $1.5 \pm 1.18$ & $1.60 \pm 1.26$ & $<0.001$ \\
\hline
\end{tabular}

NA-not applicable; **Significantly different over vs signif; *Not significantly different.

Analysis between groups shows that peak torque is higher and equivalent in VST and ST groups and much lower in the VS group, probably due to the higher age group of the VS group and the percentage distribution of severity levels among the three groups. This probability is supported by the positive correlation found between age and radiological severity of the sample, which shows slight correlation in the VST group, poor correlation in the ST group and moderate correlation in the VS group (Table 2). In this regard, the use of the isokinetic dynamometer enables rapid and reliable quantification of muscle function, analyzing dinapenia between groups and quantifying torque, power and work. ${ }^{23}$

Age and radiological classification are known to account for isokinetic and isometric torque differences in $\mathrm{KOA}$. $5,6,7$ There is a greater reduction in extensor torque than flexor torque, and muscle strength is generally associated with pain level and radiological severity, especially in patients over 51 years old. ${ }^{24}$

These results are similar to those found in this paper, in the analysis of the isokinetic response of the PRE moment. However, there is a higher mean isokinetic strength of knee extensors than flexors, in the four moments and in the three groups.

This difference is attributed to the absence in this work of a control group. It is noteworthy that in these studies there is as a common limitation only the observation of the acute effect of isokinetic force, in a single moment. In contrast, this study compared it at four different times and after two different interventions. This way, both short- and long-term benefits were effectively shown in the isokinetic response with maintenance of these benefits after the detraining period (Table 1), being similar to the results found by Gentil et al. ${ }^{25}$ and by Correa et al. ${ }^{26}$ These authors evaluated elderly and sedentary, without joint disease, but the present study evaluated women with an average age above 61 years and with

Table 1. Demographic and Clinical Characteristics of participants in different intervention study groups.

\begin{tabular}{|c|c|c|c|c|}
\hline & Viscosupplementation + Training $(n=10)$ & Training $(n=10)$ & Viscosupplementation $(n=10)$ & p-value \\
\hline Age (years) & $61.90 \pm 7.23$ & $64.00 \pm 8.82$ & $67.80 \pm 9.31$ & NA \\
\hline Height $(\mathrm{cm})$ & $160.70 \pm 6.55$ & $159.60 \pm 6.90$ & $157.00 \pm 3.94$ & NA \\
\hline Body weight $(\mathrm{kg})$ & $78.42 \pm 11.93$ & $74.72 \pm 13.7$ & $82.43 \pm 10.23$ & NA \\
\hline $\mathrm{BMI}\left(\mathrm{kg} / \mathrm{m}^{2}\right)$ & $30.41 \pm 4.68$ & $29.58 \pm 4.00$ & $33.45 \pm 4.12$ & NA \\
\hline Osteoarthritis L II & 7 & 8 & 5 & NA \\
\hline Osteoarthritis L III & 3 & 2 & 5 & NA \\
\hline
\end{tabular}


$\mathrm{KOA}$, which indicates relevance to the results obtained. Few studies have evaluated the effect of both VIS and ST on the isokinetic response. Miltner et al. ${ }^{27}$ concluded that patients treated with sodium hyaluronate have a higher peak extensor and flexor torque, which reduces resting pain and improved joint function. Diracoglu et al. ${ }^{28}$ concluded that VIS promoted short-term increase in isokinetic muscle strength with improvement in patients' functional conditions. These two studies confirm the improvement promoted by VIS in the acute isokinetic response. For this reason, in this study, three interventions were compared at four times with different attributes, before and after a treatment phase, with a single dose of VIS (15), with an association of VIS and ST and only with ST. The results indicate benefits in both acute and chronic effects, which, although without statistical differences, show a slight increase in peak torque at POSTT, remaining at POST D, with some reduction compared to POS T and still greater than the PRE moment, both in flexor and extensor strength, in both groups, with a significant advantage for the VST over the VS group. This suggests a possible benefit from the association of interventions (Table 3). As for the direct effect of VIS on the PRE and Post-VS moments measured by VAS, a significant difference is observed when compared to the PRE moment (Table 3), confirming results found in a large number of previous studies that evaluated the pain response reported in patients undergoing VIS (12-16), which is its greatest benefit. It should be remembered that, in the selection of research participants, only those with VAS $\geq 6$, value defined as for PRE phase, were admitted. In the POST-VS phase, all patients indicated VAS $\leq$ 5 (Table 3), defining that VIS is effective in reducing pain, both immediate and long term, because its analgesic effect was significantly different from POST and POS D in the viscosupplemented groups. (Table 3)

The present study becomes relevant as it also evaluates the effects of ST when comparing the VS with the VST and ST groups and presents significant differences in flexor and extensor peak torque in relation to the PRE phase in the trained groups. (Table 3) This clarifies the differential that ST provides: although not statistically significant, it shows equivalence between the VST and ST groups at the POST time in the extensor isokinetic response and a better result at the same time in the flexor isokinetic response in the VST than in the ST group (Table 3). However, it was observed an equivalent maintenance of the gains obtained by these two groups in the POST D phase, both in extensor torque and flexor torque (Table 3), confirming what has already been discussed about detraining. Analyzing the pain referred by the ST group, it is observed that training also promotes pain reduction with maintenance of the benefits obtained, but less than that observed in the groups submitted to VIS, but not less efficient (Table 3). It should be taken into account the fact that in the VST group were the patients with the highest radiological severity and the lowest average age (Table 1). Therefore, the hypothesis that the association would be more effective than each intervention alone was not confirmed. Though the results suggest a greater benefit from the association of interventions: VIS reducing pain and improving function ${ }^{12-16}$ and ST providing better mechanical efficiency, pain reduction and anti-inflammatory action, 10,29,30 with sustained effect after detraining.

\section{CONCLUSION}

This study supports the idea that the intervention in muscle strength promoted by its training continues to be an excellent non-pharmacological therapeutic option for the treatment of knee osteoarthritis, as it proves to be superior to viscosupplementation alone. Moreover, the treatment of knee osteoarthritis in relation to the isokinetic response should not be based solely on viscosupplementation. Further studies may show the possibility of generalizing these recommendations.

All authors declare no potential conflict of interest related to this article

AUTHORS' CONTRIBUTIONS: Each author made significant individual contributions to this manuscript. PCH: bibliographic research, methodology and design and study, writing the texts, discussion and conclusion; HLM: guidance on strength training methodology, critical content review; TGP: application of the evaluation scales and strength training; VRAC: statistical analysis, description of the results; EBN: isokinetic evaluations; JISN: guidance on the isokinetic analysis methodology, critical content review, final approval of the version of the manuscript to be published. All the authors reviewed and approved the final version of the manuscript

\section{REFERENCES}

1. Berenbaum F. Osteoarthritis as an inflammatory disease (osteoarthritis is not osteoarthrosis!). Osteoarthritis Cartilage. 2013;21(1):16-21.

2. Dwivedi S. Oxidative stress and role of antioxidant in osteoarthritis \& rheumatoid arthritis: a review article. Inter J Innov Res Dev. 2014; 3(9):225-36.

3. Moyer RF, Ratneswaran A, Beier F, Birmingham TB. Osteoarthritis year in review 2014: mechanics--basic and clinical studies in osteoarthritis. Osteoarthritis Cartilage. 2014;22(12):1989-2002.

4. Bennell KL, Hinman RS. A review of the clinical evidence for exercise in osteoarthritis of the hip and knee. J Sci Med Sport. 2011;14(1):4-9.

5. Jan MH, Lai JS, Tsauo JY, Lien IN. Isokinetic study of muscle strength in osteoarthritic knees of females. J Formos Med Assoc. 1990;89(10):873-9.

6. Teixeira LF, Olney SJ. Avaliação clínica, radiológica e estudo isocinético da força muscular em pacientes idosos portadores de osteoartrite (OA) do joelho. Rev Fisioter Univ São Paulo. 1995; 2(2): 56-64.

7. Wessel J. Isometric strength measurements of knee extensors in women with osteoarthritis of the knee. J Rheumatol. 1996;23(2):328-31.

8. McCarthy CJ, Oldham JA. The effectiveness of exercise in the treatment of osteoarthritic knees: a critical review. J Physical Therapy Reviews. 1999;4(4):241-50.

9. Petrella RJ. Is exercise effective treatment for osteoarthritis of the knee? Br J Sports Med. 2000;34(5):326-31.

10. Fransen M, McConnell S, Harmer AR, van der Esch M, Simic M, Bennell KL. Exercise for osteoarthritis of the knee: a Cochrane systematic review. Br J Sports Med. 2015;49(24):1554-7.

11. Coimbra IB, Pastor EH, Greve JM, Puccinelli ML, Fuller R, Cavalcanti FS, et al. Consenso brasileiro para o tratamento da osteoartrite (artrose). Rev Bras Reumatol. 2002;42(6):371-4.

12. Campbell KA, Erickson BJ, Saltzman BM, Mascarenhas R, Bach BR, Jr, Cole BJ, et al. Is local viscosupplementation injection clinically superior to other therapies in the treatment of osteoarthritis of the knee: a systematic review of overlapping meta-analyses. arthroscopy. 2015;31(10):2036-45.e14

13. Henrotin Y, Raman R, Richette P, Bard H, Jerosch J, Conrozier T, et al. Consensus statement on viscosupplementation with hyaluronic acid for the management of osteoarthritis. Semin Arthritis Rheum. 2015;45(2):140-9.

14. Moskowitz RW, Altman RD. Efficacy of intra articular hyaluronan in the treatment of knee osteoarthritis: comment on the article by Brandt et al. Arthritis Rheum. 2000;44(6):1471-3.

15. Chevalier X, Jerosch J, Goupille P, van Dijk N, Luyten FP, Scott DL, et al. Single, intra-articular treatment with $6 \mathrm{ml}$ hylan G-F 20 in patients with symptomatic primary osteoarthritis of the knee: a randomised, multicentre, double-blind, placebo controlled trial. Ann Rheum Dis. 2010; 69(1):113-9.

16. Conrozier T, Walliser-Lohse A, Richette P, et al. Intra articular injections of Hylan GF-20 reduce type 2 collagen degradation in patients with knee osteoarthritis: the biovisco study. Ann Rheum Dis. 2010;69(Suppl 3):281.

17. Santos LR, Zazá DC, Andrade AG, Athayde SW, Chagas MH. Relação entre a força muscular de membros inferiores e o desempenho em testes funcionais em idosos. Coleção Pesquisa em Educação Física. 2008; $7(2): 295-300$.

18. Oliveira AM, Peccin MS, Silva KN, Teixeira LE, TrevisaniVF. Impact of exercise on the functional capacity and pain of patients with knee osteoarthritis: a randomized clinical trial. Rev Bras Reumatol. 2012; 52(6):876-82

19. Kellgren JH, Lawrence JS. Radiological assessment of osteo-arthrosis. Ann Rheum Dis. 1957;16(4):494-502.

20. Altman R, Asch E, Bloch D, Bole G, Borenstein D, Brandt K, et al. Development of criteria for the classification and reporting of osteoarthritis. Classification of osteoarthritis of the knee. Diagnostic and Therapeutic Criteria Committee of the American Rheumatism Association. Arthritis Rheum. 1986;29(8):1039-49.

21. Badillo GJ, Ayestarán GE. Componentes do treinamento de força. In: Badillo GJ, Ayestarán GE (editors). Fundamentos de força - aplicação ao alto rendimento desportivo. 2. ed. Porto Alegre, Rio Grande do Sul: Artmed; 2001. p. 133-63.

22. Baechle TR, Earle RW. Essentials of strength training and conditioning. 3. ed. Human Kinetics, 2008.

23. Dvir Z. Isocinética dos músculos do joelho. In: Dvir Z (editor). Isocinética: Avaliações musculares, interpretações e aplicações clinicas. 1. ed. Barueri, São Paulo: Manole; 2002. p. 101-23

24. Muraki S, Akune T, Teraguchi M, Kagotani R, Asai Y, Yoshida M, et al. Quadriceps muscle strength, radiographic knee osteoarthritis and knee pain: the ROAD study. BMC Musculoskelet Disord. 2015;16:305.

25. Gentil P, Ferreira-Junior JB, Soares SR, Martorelli AS, Bottaro M, Cadore EL, et al. Effects of periodic and continuous resistance training on muscle strength in detrained women. percept mot skills. 2015;121(3):810-21.

26. Correa CS, Cunha G, Marques N, Oliveira-Reischak Ã, Pinto R. Effects of strength training, detraining and retraining in muscle strength, hypertrophy and functional tasks in older female adults. Clin Physiol Funct Imaging. 2016;36(4):306-10.

27. Miltner O, Schneider U, Siebert CH, Wirtz DC, Niethard FU. [Measuring isokinetic force in patients with gonarthrosis before and after hyaluronic acid therapy]. Z Orthop Ihre Grenzgeb. 2001;139(4):340-5.

28. Diracoglu D, Vural M, Baskent A, Dikici F, Aksoy C. The effect of viscosupplementation on neuromuscular control of the knee in patients with osteoarthritis. J Back Musculoskelet Rehabil. 2009;22(1):1-9.

29. Golightly YM, Allen KD, Caine DJ. A comprehensive review of the effectiveness of different exercise programs for patients with osteoarthritis. Phys Sportsmed. 2012:40(4):52-65.

30. Helmark IC, Mikkelsen UR, Borglum J, Rothe A, Petersen MC, Andersen O, et al. Exercise increases interleukin-10 levels both intraarticularly and peri-synovially in patients with knee osteoarthritis: a randomized controlled trial. Arthritis Res Ther. 2010:12(4):R126. 